\title{
Synthesis, Characterization, and Catalytic Studies of Mn(III)-Schiff Base-Dicyanamide Complexes: Checking the Rhombicity Effect in Peroxidase Studies
}

\author{
Manuel R. Bermejo, ${ }^{1}$ Rocío Carballido, ${ }^{2}$ M. Isabel Fernández-García, ${ }^{2}$ \\ Ana M. González-Noya, ${ }^{1}$ Gustavo González-Riopedre, ${ }^{2}$ Marcelino Maneiro, ${ }^{2}$ \\ and Laura Rodríguez-Silva ${ }^{2}$ \\ ${ }^{1}$ Department of Inorganic Chemistry, Faculty of Chemistry, Universidade de Santiago de Compostela, \\ 15782 Santiago de Compostela, Spain \\ ${ }^{2}$ Department of Inorganic Chemistry, Faculty of Sciences, Universidade de Santiago de Compostela, 27002 Lugo, Spain
}

Correspondence should be addressed to Manuel R. Bermejo; manuel.bermejo@usc.es

Received 2 February 2017; Accepted 4 July 2017; Published 16 August 2017

Academic Editor: Albert Demonceau

Copyright (C) 2017 Manuel R. Bermejo et al. This is an open access article distributed under the Creative Commons Attribution License, which permits unrestricted use, distribution, and reproduction in any medium, provided the original work is properly cited.

\begin{abstract}
The condensation of 3-methoxy-2-hydroxybenzaldehyde and the diamines 1,2-diphenylendiamine, 1,2-diamine-2-methylpropane and 1,3-propanediamine yielded the dianionic tetradentate Schiff base ligands N,N' -bis(2-hydroxy-4-methoxybenzylidene)-1,2-diphenylendiimine $\left(\mathrm{H}_{2} \mathrm{~L}^{1}\right)$, N,N'-bis(2-hydroxy-4-methoxybenzylidene)-1,2-diamino-2-methylpropane $\left(\mathrm{H}_{2} \mathrm{~L}^{2}\right)$ and $\mathrm{N}, \mathrm{N}^{\prime}$-bis $(2$ hydroxy-4-methoxybenzylidene)-1,3-diaminopropane $\left(\mathrm{H}_{2} \mathrm{~L}^{3}\right)$ respectively. The organic compounds $\mathrm{H}_{2} \mathrm{~L}^{1}$ and $\mathrm{H}_{2} \mathrm{~L}^{2}$ have been characterized by elemental analysis, IR, ${ }^{1} \mathrm{H}$ and ${ }^{13} \mathrm{C}$ NMR spectroscopies and mass spectrometry electrospray (ES). The crystal

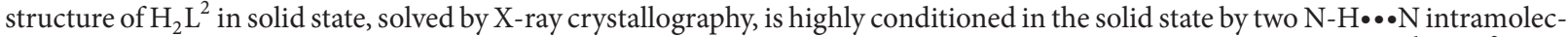
ular interactions. The synthesis of three new manganese(III) complexes 1-3, incorporating these ligands, $\mathrm{H}_{2} \mathrm{~L}^{1}-\mathrm{H}_{2} \mathrm{~L}^{3}$, and dicyanamide (DCA), is reported. The complexes 1-3 have been physicochemically characterized by elemental analysis, IR and paramagnetic ${ }^{1} \mathrm{H}$ NMR spectroscopy, ESI mass spectrometry, magnetic moment at room temperature and conductivity measurements. Complex 1 has been crystallographically characterized. The X-ray structure shows the self-assembly of the Mn(III)-Schiff base-DCA complex through $\mu$-aquo bridges between neighbouring axial water molecules and also by $\pi$ - $\pi$ stacking interactions, establishing a dimeric structure. The manganese complexes were also tested as peroxidase mimics for the $\mathrm{H}_{2} \mathrm{O}_{2}$-mediated reaction with the water-soluble trap ABTS, showing complexes 1-2 relevant peroxidase activity in contrast with $\mathbf{3}$. The rhombicity around the metal ion can explain this catalytic behaviour.
\end{abstract}

\section{Introduction}

Schiff base ligands stabilize different metal ions in solution to yield metal complexes with a variety of properties and applications. For instance, one of these ligands, the chelating salen, is known by the ability to significantly decrease the $\mathrm{Mn}(\mathrm{III}) / \mathrm{Mn}(\mathrm{II})$ redox potentials, and the resulting complexes constitute suitable systems to catalyse multiple redox reactions such as asymmetric epoxidation of unfunctionalized olefins, catalase reaction, water photolysis, Diels-Alder cycloaddition, enantioselective cyclopropanation of styrenes and ring opening of epoxides [1-8]. Over the past years, a variety of applications of this type of complexes has also been reported, including a broad range of biological activities (antibacterial, antifungal, anticancer, antioxidant, anti-inflammatory, etc.) [9-13].

During our search for new metal catalysts containing salen-type ligands, we have observed a better catalytic behaviour when the substrate molecule can be easily coordinated by the complex and this is favoured when the catalyst has either a vacancy in the coordination sphere or a labile ligand [14-17]. To achieve this, 

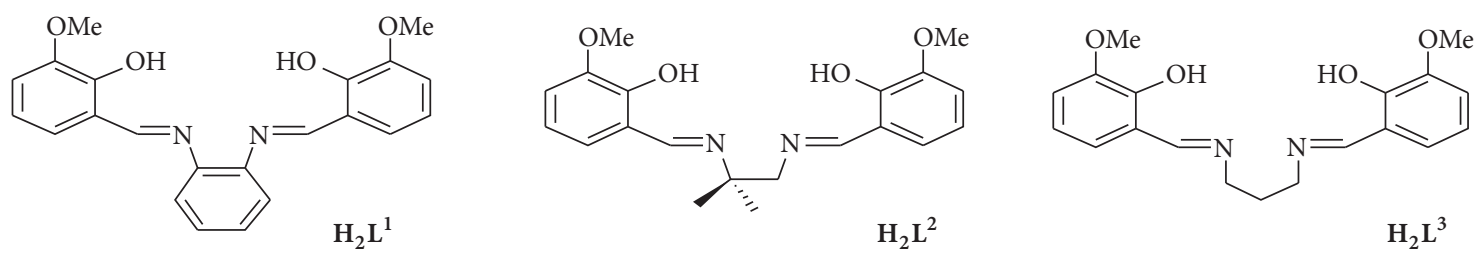

FIgURE 1: Structures of the Schiff base ligands $\mathrm{H}_{2} \mathrm{~L}^{1}-\mathrm{H}_{2} \mathrm{~L}^{3}$.

a careful design of the environment around the metal ion is necessary.

In this article, we report the synthesis and characterization of three new complexes containing both salen-type ligands and ancillary dicyanamide ligands (see Figure 1). The two imine nitrogen and two phenol oxygen atoms of the tetradentate Schiff bases $\mathrm{H}_{2} \mathrm{~L}^{1}-\mathrm{H}_{2} \mathrm{~L}^{3}$ constitute an inner ONNO site. The presence of the outer methoxy groups facilitates the extension of the supramolecular network through hydrogen-bond interactions $[18,19]$. Our scheme consists of inducing tetragonal elongation around the manganese ion with the combination of the $\mathrm{H}_{2} \mathrm{~L}^{n}$ and dicyanamide ligands.

These complexes may behave like enzyme mimics, and their peroxidase activity is reported in this work. Peroxidases catalyse oxidation of a broad range of substrates by hydrogen hydroxide, so they may be successfully used for different industrial processes since peroxidases are capable of degrading aromatic rings in lignin, dyes, and polycyclic aromatic hydrocarbons $[15,16,20,21]$. In this sense, dyes are regarded as one of the most important contaminants to be removed from the industrial effluents, and peroxidases arise as a way to treat these pollutants. Here we check the peroxidase activity of $\mathrm{Mn}$ (III)-Schiff base complexes in function of the rhombicity (or tetragonal elongation) around the manganese ion.

\section{Materials and Methods}

2.1. Materials. All solvents, 3-methoxy-2-hydroxybenzaldehyde, 1,2-diphenylendiamine, 1,2-diamine-2-methylpropane, 1,3-propanediamine, manganese(II) acetate, sodium dicyanamide, hydrogen peroxide, and 2,2' -azinobis-(3-ethylbenzothiazoline)-6-sulfonic acid, are commercially available and were used without further purification.

2.2. Physical Measurements. Elemental analyses of $\mathrm{C}, \mathrm{H}$, and $\mathrm{N}$ were performed on a Carlo Erba EA-1108. IR spectra were recorded as $\mathrm{KBr}$ discs on a Bio-Rad FTS135 spectrophotometer in the range $4000-400 \mathrm{~cm}^{-1} .{ }^{1} \mathrm{H}$ NMR and ${ }^{13} \mathrm{C} N M R$ spectra were recorded on a Bruker AC-300 spectrometer at $296 \mathrm{~K}$ using DMSO- $\mathrm{d}_{6}$ as deuterated solvent and tetramethylsilane as an internal reference. Positive electrospray-ionization (ESI) mass spectra of the ligands and complexes were recorded on a LC-MSD 1100 Hewlett-Packard instrument (positive-ion mode, 98:2 $\mathrm{CH}_{3} \mathrm{OH} / \mathrm{HCOOH}$ as the mobile phase, 30-100 V). Magnetic susceptibilities were measured at room temperature using a Sherwood-Scientific MK1 balance, calibrated using mercury tetrakis(isothiocyanato)cobaltate(II), $\mathrm{Hg}\left[\mathrm{Co}(\mathrm{NCS})_{4}\right]$. Measurements of conductivity were made with $10^{-3} \mathrm{M}$ solutions of complexes in dimethylformamide using a Crison microCM 2200 conductivimeter.

2.3. Synthesis of $\mathrm{H}_{2} \mathrm{~L}^{1}$. Schiff base ligand $\mathrm{H}_{2} \mathrm{~L}^{1}$ was prepared according to the literature by condensation of 3-methoxy-2-hydroxybenzaldehyde $(1.12 \mathrm{~g}, 10.35 \mathrm{mmol})$ with 1,2 phenylenediamine $(0.54 \mathrm{~mL}, 5.18 \mathrm{mmol})$ in methanol [28]. The mixture of diamine and salicylaldehyde was refluxed in a round bottom flask fitted with a Dean-Stark apparatus. After heating for $3 \mathrm{~h}$, the solution was concentrated to yield an orange solid. The product was collected by filtration, washed with diethyl ether, and dried in air. Yield was almost quantitative. M.p. $172.5^{\circ}$ C. Anal. Calc. for $\mathrm{C}_{22} \mathrm{H}_{20} \mathrm{~N}_{2} \mathrm{O}_{4}$ : C, 70.2; H, 5.3; N, 7.4. Found: C, 70.1; H, 5.3, N, 7.5\%. MS ES $(m / z): 377\left(\mathrm{~L}+\mathrm{H}^{+}\right)^{+}$; IR $\left(\mathrm{KBr}, \mathrm{cm}^{-1}\right): \nu(\mathrm{O}-\mathrm{H}) 3461, v(\mathrm{C}=\mathrm{N})$ 1611, $v(\mathrm{C}-\mathrm{O}) 1253 .{ }^{1} \mathrm{H}$ NMR (DMSO-d $\left.{ }_{6}, \mathrm{ppm}\right): \delta 12.95$ (s, 2H), $8.88(\mathrm{~s}, 2 \mathrm{H}), 7.42(\mathrm{~m}, 4 \mathrm{H}), 7.36(\mathrm{~d}, 2 \mathrm{H}), 7.13(\mathrm{~d}, 2 \mathrm{H}), 6.88(\mathrm{t}$, $2 \mathrm{H}), 3.79(\mathrm{~s}, 6 \mathrm{H}) .{ }^{13} \mathrm{C} \mathrm{NMR}\left(\mathrm{DMSO}_{6}, \mathrm{ppm}\right): \delta 164.8(\mathrm{C}=\mathrm{N})$, $151.4\left(\mathrm{C}-\mathrm{OCH}_{3}\right), 142.8(\mathrm{C}-\mathrm{OH}), 116-128.5\left(\mathrm{C}_{\mathrm{ar}}\right), 40.2\left(\mathrm{CH}_{3}\right)$.

2.4. Synthesis and Crystallization of $\mathrm{H}_{2} \mathrm{~L}^{2}$. The tetradentate Schiff base $\mathrm{H}_{2} \mathrm{~L}^{2}$ was prepared following the procedure already described for $\mathrm{H}_{2} \mathrm{~L}^{1}$, using 3-methoxy-2-hydroxybenzaldehyde $(2.00 \mathrm{~g}, 13.14 \mathrm{mmol})$ and 1,2-diamine-2-methylpropane $(0.68 \mathrm{~mL}, 6.57 \mathrm{mmol})$ in methanol. The yellow product was collected by filtration, washed with diethyl ether, and dried in air. Yellow crystals of $\mathrm{H}_{2} \mathrm{~L}^{2}$, suitable for single crystal $\mathrm{X}$-ray diffraction studies, were obtained by slow evaporation of the methanol solution of the ligands. Yield was almost quantitative, $94 \%$. M.p. $122.9^{\circ}$ C. Anal. Calc. for $\mathrm{C}_{20} \mathrm{H}_{24} \mathrm{~N}_{2} \mathrm{O}_{4}$ : C, 67.4; H, 6.8; N, 7.9. Found: C, 67.3; H, 6.7, N, 7.8\%. MS ES $(\mathrm{m} / z): 357\left(\mathrm{~L}+\mathrm{H}^{+}\right)^{+}, 379\left(\mathrm{~L}+\mathrm{Na}^{+}\right)^{+} ; \mathrm{IR}\left(\mathrm{KBr}, \mathrm{cm}^{-1}\right): \nu(\mathrm{O}-\mathrm{H})$ 3441, $v(\mathrm{C}=\mathrm{N}) 1630, v(\mathrm{C}-\mathrm{O}) 1256 .{ }^{1} \mathrm{H}$ NMR (DMSO-d $\left.{ }_{6}, \mathrm{ppm}\right)$ : $\delta 8.53,8.50(\mathrm{~s}, 2 \mathrm{H}), 6.77-7.01(\mathrm{~m}, 6 \mathrm{H}), 3.83(\mathrm{~m}, 6 \mathrm{H}), 3.76(\mathrm{t}$, $4 \mathrm{H}), 1.37(\mathrm{t}, 6 \mathrm{H}),{ }^{13} \mathrm{C}$ NMR (DMSO- $\left.\mathrm{d}_{6}, \mathrm{ppm}\right): \delta 163.3(\mathrm{C}=\mathrm{N})$, $148.9\left(\mathrm{C}-\mathrm{OCH}_{3}\right), 152.9(\mathrm{C}-\mathrm{OH}), 25.7\left(\mathrm{CH}_{3}\right)$.

2.5. Synthesis of $\mathrm{H}_{2} \mathrm{~L}^{3}$. The synthesis and characterization of $\mathrm{H}_{2} \mathrm{~L}^{3}$ have been already previously reported and they will not be discussed in this paper [22].

2.6. Complex Preparation. $\mathrm{Mn}_{2} \mathrm{~L}_{2}{ }_{2}\left(\mathrm{H}_{2} \mathrm{O}\right)_{2}(\mathrm{DCA})_{2}$ (1): to a methanolic solution of $\mathrm{H}_{2} \mathrm{~L}^{1}(0.53 \mathrm{mmol}, 0.20 \mathrm{~g}), 0.53 \mathrm{mmol}$ $(0.13 \mathrm{~g})$ of $\mathrm{Mn}\left(\mathrm{CH}_{3} \mathrm{COO}\right)_{2}$ was added and the stirred solution changed its initial yellow colour to brown. After 30 minutes of 
stirring with gentle heating, $0.53 \mathrm{mmol}(0.05 \mathrm{~g})$ of $\mathrm{NaN}(\mathrm{CN})_{2}$ in $10 \mathrm{~mL}$ of methanol was added. The solution was then concentrated by slow evaporation. The complex was obtained as brown crystals, which were isolated by filtration, washed with diethyl ether, and dried in air. Yield 60\%. Anal. Calcd. for $\mathrm{C}_{48} \mathrm{H}_{40} \mathrm{Mn}_{2} \mathrm{~N}_{10} \mathrm{O}_{10}$ (1026.8): C, 56.1; H, 3,9; N, 13.6. Found: C, 55.5; H, 3.9; N, 13.4\%. MS ES $(m / z): 429[\mathrm{MnL}]^{+} ; 496$ $[\mathrm{MnL}(\mathrm{DCA})]^{+}$. IR $\left(\mathrm{KBr}, \mathrm{cm}^{-1}\right): v(\mathrm{O}-\mathrm{H}) 3433(\mathrm{~m}), v(\mathrm{C}=\mathrm{N})$ 1600 (vs), $v(\mathrm{C}-\mathrm{O}) 1258(\mathrm{~s}), v_{\text {sym }}(\mathrm{C} \equiv \mathrm{N}) 2151$ (vs), $v_{\text {asym }}(\mathrm{C} \equiv \mathrm{N})$ $2254(\mathrm{~m}) .{ }^{1} \mathrm{H}$ NMR (DMSO-d 6 , ppm): $\delta-14.9$ (H4), -20.0 (H5). $\mu=4.8 \mathrm{BM}$. Conductivity (in DMF) $\Lambda_{\mathrm{M}}=45 \mu \mathrm{S}$.

$\left[\mathrm{MnL}^{2}\left(\mathrm{H}_{2} \mathrm{O}\right)(\mathrm{DCA})\right]\left(\mathrm{H}_{2} \mathrm{O}\right)(2)$ was obtained by the same procedure as 1 , using $0.46 \mathrm{mmol}(0.16 \mathrm{~g})$ of $\mathrm{H}_{2} \mathrm{~L}^{2}, 0.46 \mathrm{mmol}$ $(0.11 \mathrm{~g})$ of $\mathrm{Mn}\left(\mathrm{CH}_{3} \mathrm{COO}\right)_{2}$, and $0.46 \mathrm{mmol}(0.04 \mathrm{~g})$ of $\mathrm{NaN}(\mathrm{CN})_{2}$ in $10 \mathrm{~mL}$ of methanol which were added. Yield 58\%. Anal. Calcd. for $\mathrm{C}_{22} \mathrm{H}_{26} \mathrm{MnN}_{5} \mathrm{O}_{6}$ (511.41): C, 51.6; $\mathrm{H}$, 5.1; N, 13.7. Found: C, 52.1; H, 5.2; N, 13.5\%. MS ES $(m / z)$ $408.5[\mathrm{MnL}]^{+}, 884.0\left[\mathrm{Mn}_{2} \mathrm{~L}_{2}(\mathrm{DCA})_{2}\right]^{+}$; IR $\left(\mathrm{KBr}, \mathrm{cm}^{-1}\right)$ : $\nu(\mathrm{O}-\mathrm{H}) 3425, v(\mathrm{C}=\mathrm{N}) 1610, v(\mathrm{C}-\mathrm{O}) 1260, v_{\text {sym }}(\mathrm{C} \equiv \mathrm{N}) 2148$, $\nu_{\text {asym }}(\mathrm{C} \equiv \mathrm{N}) 2266 ;{ }^{1} \mathrm{H}$ NMR (DMSO-d $\left.{ }_{6}, \mathrm{ppm}\right): \delta-15.2(\mathrm{H} 4)$, $-16.8 /-25.0$ (H5). $\mu=5.0$ BM. Conductivity (in MeOH) $\Lambda_{M}=$ $46 \mu \mathrm{S}$.

$\left[\mathrm{MnL}^{3}\left(\mathrm{H}_{2} \mathrm{O}\right)(\mathrm{DCA})\right]\left(\mathrm{H}_{2} \mathrm{O}\right)(3)$ was obtained by the same procedure as 1 , using $0.58 \mathrm{mmol}(0.20 \mathrm{~g})$ of $\mathrm{H}_{2} \mathrm{~L}^{3}, 0.58 \mathrm{mmol}$ $(0.14 \mathrm{~g})$ of $\mathrm{Mn}\left(\mathrm{CH}_{3} \mathrm{COO}\right)_{2}$, and $0.58 \mathrm{mmol}(0.05 \mathrm{~g})$ of $\mathrm{NaN}(\mathrm{CN})_{2}$ in $10 \mathrm{~mL}$ of methanol which were added. Yield 65\%. Anal. Calcd. for $\mathrm{C}_{21} \mathrm{H}_{24} \mathrm{MnN}_{5} \mathrm{O}_{6}$ (497.37): C, 50.7; $\mathrm{H}$, 4.8; N, 14.1. Found: C, 49.8; H, 4.6; N, 13.8\%. MS ES $(\mathrm{m} / z)$ $395.3\left[_{\mathrm{MnL}}^{+}\right.$; IR $\left(\mathrm{KBr}, \mathrm{cm}^{-1}\right): \nu(\mathrm{O}-\mathrm{H}) 3412, v(\mathrm{C}=\mathrm{N}) 1612$, $\nu(\mathrm{C}-\mathrm{O}) 1256, \nu_{\text {sym }}(\mathrm{C} \equiv \mathrm{N}) 2144, \nu_{\text {asym }}(\mathrm{C} \equiv \mathrm{N}) 2252 ;{ }^{1} \mathrm{H} \mathrm{NMR}$ (DMSO-d $\left.{ }_{6}, \mathrm{ppm}\right): \delta-16.4$ (H4), -18.6 (H5). $\mu=4.7$ BM. Conductivity (in DMF) $\Lambda_{\mathrm{M}}=42 \mu \mathrm{S}$.

2.7. Peroxidase Probes. Peroxidase activity for complexes 1-3 was tested according to the literature procedure $[15,16]$ by study of the oxidation of 2,2' -azinobis-(3-ethylbenzothiazoline)-6-sulfonic acid (ABTS) with $\mathrm{H}_{2} \mathrm{O}_{2}$ at ca. $\mathrm{pH} 6.8$ in the presence of the complexes.

2.8. Crystallographic Studies. Single crystals of $\mathrm{H}_{2} \mathrm{~L}^{2}$ and complex 1, suitable for X-ray diffraction studies, were obtained by slow evaporation of the methanolic solution at room temperature.

Table 1 collects detailed crystal data collection and refinement for $\mathrm{H}_{2} \mathrm{~L}^{2}$ and complex 1 . Measurements were made on a Bruker-Smart CCD-1000 diffractometer employing graphitemonochromated $M o-K \alpha$ radiation $(\lambda=0.71073 \AA)$ at $100 \mathrm{~K}$. The structures were solved by direct methods [29] and finally refined by full-matrix least-squares base on $F^{2}$. An empirical absorption correction was applied using SADABS [30]. All nonhydrogen atoms were included in the model at geometrically calculated positions.

Refinement of $F^{2}$ against all reflections: the weighted $R$ factor $w R$ is based on $F 2$, and conventional $R$-factors $R$ are based on $F$, with $F$ set to zero for negative $F^{2}$. The threshold expression of $F^{2}>2 \sigma\left(F^{2}\right)$ is used only for calculating $R$ factors(gt) and so forth and is not relevant to the choice
TABLE 1: Crystal data and structure refinement for $\mathrm{H}_{2} \mathrm{~L}^{2}$ and complex 1 .

\begin{tabular}{|c|c|c|}
\hline & $\mathrm{H}_{2} \mathrm{~L}^{2}$ & Complex 1 \\
\hline Chemical formula & $\mathrm{C}_{20} \mathrm{H}_{24} \mathrm{~N}_{2} \mathrm{O}_{4}$ & $\mathrm{C}_{24} \mathrm{H}_{20} \mathrm{MnN}_{5} \mathrm{O}_{5}$ \\
\hline Formula weight & 356.41 & 513.39 \\
\hline Crystal system & Triclinic & Triclinic \\
\hline Space group & $P \overline{1}$ & $P \overline{1}$ \\
\hline Temperature $(\mathrm{K})$ & 100 & $100(2)$ \\
\hline$a(\AA)$ & $8.3632(6)$ & $8.3157(4)$ \\
\hline$b(\AA)$ & $10.5626(7)$ & $11.9711(6)$ \\
\hline$c(\AA)$ & $11.4846(7)$ & $12.7633(10)$ \\
\hline$\alpha\left({ }^{\circ}\right)$ & $108.689(2)$ & $114.321(3)$ \\
\hline$\beta\left(^{\circ}\right)$ & $95.176(2)$ & $102.633(3)$ \\
\hline$\gamma\left({ }^{\circ}\right)$ & $103.965(2)$ & $97.626(2)$ \\
\hline Volume $\left(\AA^{3}\right)$ & $917.00(11)$ & 1093.74(11) \\
\hline$Z$ & 2 & 2 \\
\hline Radiation type & Mo $K \alpha$ & Mo $K \alpha$ \\
\hline$\mu\left(\mathrm{mm}^{-1}\right)$ & 0.09 & 0.653 \\
\hline Crystal size (mm) & $0.2 \times 0.11 \times 0.03$ & $0.12 \times 0.11 \times 0.06$ \\
\hline$T_{\min }, T_{\max }$ & $0.942,0.997$ & $0.9619,0.9858$ \\
\hline$F(000)$ & 380 & 528 \\
\hline Number of measured reflections & 11933 & 20087 \\
\hline Number independent reflections & 3607 & 4293 \\
\hline Reflections observed $[I>2 \sigma(I)]$ & 2055 & 3209 \\
\hline$R_{\text {int }}$ & 0.054 & 0.0374 \\
\hline$(\sin \theta / \lambda)_{\max }\left(\AA^{-1}\right)$ & 0.617 & 0.0752 \\
\hline$R\left[F^{2}>2 \sigma\left(F^{2}\right)\right]$ & 0.049 & 0.0630 \\
\hline$w R\left(F^{2}\right)$ & 0.128 & 0.0816 \\
\hline Number of parameters & 247 & 332 \\
\hline$\Delta_{\max }, \Delta_{\min }\left(\mathrm{e} \AA^{-3}\right)$ & $0.31,-0.28$ & $0.338,-0.423$ \\
\hline
\end{tabular}

of reflections for refinement. $R$-factors based on $F^{2}$ are statistically about twice as large as those based on $F$, and $R$ factors based on all data will be even larger.

\section{Results and Discussion}

Schiff bases $\mathrm{H}_{2} \mathrm{~L}^{1}-\mathrm{H}_{2} \mathrm{~L}^{2}$ have been obtained in almost quantitative yield and characterized by elemental analysis, IR, ${ }^{1} \mathrm{H}$, and ${ }^{13} \mathrm{C}$ NMR spectroscopies, and mass spectrometry electrospray (ES). The synthesis and characterization of $\mathrm{H}_{2} \mathrm{~L}^{3}$ have been already reported [22].

Complexes 1-3 were prepared in high yield as detailed in the Materials and Methods. Elemental analysis establishes the general formula $\left[\mathrm{MnL}^{n}\left(\mathrm{H}_{2} \mathrm{O}\right)(\mathrm{DCA})\right]\left(\mathrm{H}_{2} \mathrm{O}\right)_{x}$, with $n=$ $1-3$ and $x=0-1$. Analytical and spectroscopic data are in accordance with this empirical formula. All the complexes seem to be stable in air and thermally stable, melting above $300^{\circ} \mathrm{C}$ without decomposition. They are insoluble or sparingly soluble in water but partially soluble in common organic solvents such as methanol and totally soluble in polar coordinating solvents such as pyridine, DMF, and DMSO.

ESI (electrospray-ionization) mass spectra registered in methanol show, for complexes 1-3, a peak corresponding 


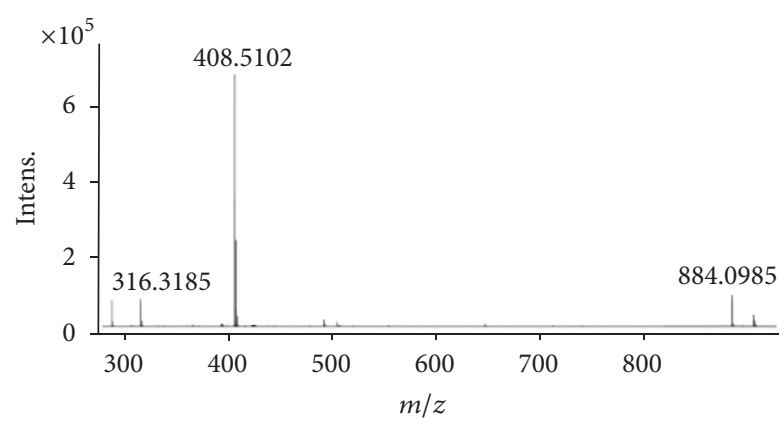

FIGURE 2: ESI mass spectrum for complex 2.

to the fragment $[\mathrm{MnL}]^{+}$, indicating the coordination of the Schiff base ligand to the metal centre. Other minor signals, assigned to $\left[\mathrm{MnL}^{1}(\mathrm{DCA})\right]^{+}$and $\left[\mathrm{Mn}_{2} \mathrm{~L}_{2}{ }_{2}(\mathrm{DCA})_{2}\right]^{+}$units, also confirm the coordination of the dicyanamide ion to the manganese ion and point to the formation of dimeric species (Figure 2).

The values for the magnetic moment at room temperature are very close to the spin-only value of $4.89 \mathrm{BM}$, as expected for a high-spin magnetically diluted $\mathrm{d}^{4}$ manganese(III) ion.

All the complexes show similar IR spectral features, exhibiting a strong band between 1600 and $1612 \mathrm{~cm}^{-1}$ attributable to $\nu\left(\mathrm{CN}_{\text {imine }}\right)$ band, which is shifted $3-7 \mathrm{~cm}^{-1}$ lower than in the free Schiff base ligand. There is also a positive shift $\left(3-7 \mathrm{~cm}^{-1}\right)$ of the $\nu\left(\mathrm{CO}_{\text {phenol }}\right)$ mode with respect to the free ligand (Figure 3 ). These data suggest the coordination of the Schiff base in its dianionic form through the inner phenol oxygen and the imine nitrogen atoms $[14,15$, 22]. Moreover, two new bands at about 2150 and $2260 \mathrm{~cm}^{-1}$ are assigned, respectively, to the symmetric and asymmetric dicyanamide modes $[16,31]$.

Paramagnetic ${ }^{1} \mathrm{H}$ NMR spectra of $\mathbf{1}-\mathbf{3}$ were registered using DMSO- $\mathrm{d}_{6}$ as solvent. The data interpretation, based on previous findings for manganese(III) complexes with related Schiff base ligands [24], indicates [32, 33] the formation of the manganese(III) complexes. The paramagnetic ${ }^{1} \mathrm{H}$ NMR spectra of the complexes contain, for all cases, two upfield proton resonances, outside the diamagnetic region $(\delta=$ $0-14 \mathrm{ppm}$ ), due to the isotropic shifting of the ligand protons for high-spin manganese(III) complexes in an octahedral field. The signals must arise from the protons of the aromatic phenoxy rings. In the case of the symmetric complexes 1 and 3 , the -20.0 (for 1 )/ -18.6 (for 3 ) signals arise from the protons in the orthopositions to the methoxy substituent, while the resonances from -14.9 (for 1)/-16.4 (for 3) ppm arise from protons in the metapositions to the methoxy substituent. For complex 2 the signal from the protons in the orthopositions to the methoxy substituent appears split in two resonances at -16.8 and -25.0 ppm (Figure 4).

\subsection{Crystallographic Characterization of $\mathrm{H}_{2} \mathrm{~L}^{2}$ and Complex $\mathbf{1}$}

3.1.1. Crystal Structure of $\mathrm{H}_{2} \mathrm{~L}^{2}$. The crystal structure reveals that $\mathrm{H}_{2} \mathrm{~L}^{2}$ exists as discrete molecules, and it is composed of two identical 3-methoxy-2-hydrobenzylimine moieties
TABLE 2: Selected geometric parameters $\left(\AA,{ }^{\circ}\right)$ for $\mathrm{H}_{2} \mathrm{~L}^{2}$.

\begin{tabular}{lc}
\hline $\mathrm{C} 12-\mathrm{N} 2$ & $1.272(3)$ \\
$\mathrm{C} 14-\mathrm{O} 3$ & $1.351(3)$ \\
$\mathrm{C} 12-\mathrm{N} 2-\mathrm{C} 9$ & $122.9(2)$ \\
$\mathrm{C} 7-\mathrm{N} 1$ & $1.279(3)$ \\
$\mathrm{C} 1-\mathrm{O} 1$ & $1.354(3)$ \\
$\mathrm{N} 2-\mathrm{C} 9-\mathrm{C} 8$ & $106.65(19)$ \\
\hline
\end{tabular}

TABLE 3: Hydrogen bonds for $\mathrm{H}_{2} \mathrm{~L}^{2}$.

\begin{tabular}{lcccc}
\hline $\mathrm{D}-\mathrm{H} \cdots \mathrm{A}(\AA)$ & $\mathrm{D}-\mathrm{H}(\AA)$ & $\mathrm{H} \cdots \mathrm{A}(\AA)$ & $\mathrm{D} \cdots \mathrm{A}(\AA)$ & $\mathrm{D}-\mathrm{H} \cdots \mathrm{A}(\AA)$ \\
\hline $\mathrm{O} 1-\mathrm{H} 1 \cdots \mathrm{N} 1$ & 0.96 & 1.73 & 2.5839 & 146 \\
$\mathrm{O} 3-\mathrm{H} 3 \cdots \mathrm{N} 2$ & 0.93 & 1.72 & 2.5891 & 154 \\
$\mathrm{C} 8-\mathrm{H} 8 \mathrm{~B} \cdots \mathrm{O} 1$ & 0.99 & 2.55 & 3.4451 & 151 \\
\hline
\end{tabular}

twisted about the central aliphatic chain which acts as a spacer (Figure 5). The C12-N2 and C7-N1 distances of 1.272(3) and $1.279(3) \AA$, respectively, are practically identical and consistent with a $\mathrm{C}=\mathrm{N}$ double bonding (Table 2), indicating both imine groups fully localized in the molecule [34]. The two oxygen $\mathrm{O} 1$ and $\mathrm{O} 3$ atoms are forming phenolic groups, and they present C-O distances of 1.354(3) $\AA$ and 1.351(3), respectively, corresponding to the expected single bonds. The C12-N2-C9 angle of $122.9(2)^{\circ}$ confirms the $\mathrm{sp}^{2}$ character for $\mathrm{N} 2$ atom [32].

The disposition adopted by the free ligand in the solid state is conditioned by two strong intramolecular hydrogenbond interactions which form two six-membered rings. These interactions arise from the contact between the hydroxy and the imine groups (see Table 3). As expected, the $\mathrm{O} 1-\mathrm{H} 1 \mathrm{O} \bullet \bullet \mathrm{N} 1$ hydrogen bonding establishes an almost planar N1-C7-C6-C1-O1-H1 ring, the same for the O3-H3O•••N2 hydrogen bonding which establishes other almost planar N2C12-C13-C14-O3-H3 rings.

Despite the mentioned intramolecular hydrogen interactions and a partial conjugation of the molecule, this one is not planar, probably due to the packing based on the intermolecular hydrogen bonds and the $\pi$-stacking interactions between the salicyl residues of the neighbouring molecules (see Figure 6). The aromatic rings are arranged almost perpendicular to each other. Clearly, rotation about the C8-C9 bond to give a near-eclipsed or gauche conformation would achieve quasi-square-planar coordination environments using the inner ONNO site. According to this crystal structure study, this ligand should act as tetradentate donor in the equatorial plane about an octahedral metal centre. However, we cannot predict the role of the outer phenoxy oxygen atoms of each aldehyde residue during complexation as they could coordinate, for instance, with the metal centre by an axial position, but also their role could be limited to intermolecular hydrogen-bond interactions.

3.1.2. Crystal Structure of $\mathbf{1}$. Single crystals of complex $\mathbf{1}$, suitable for X-ray diffraction studies, were obtained as described in the Materials and Methods. The crystal structure is shown 


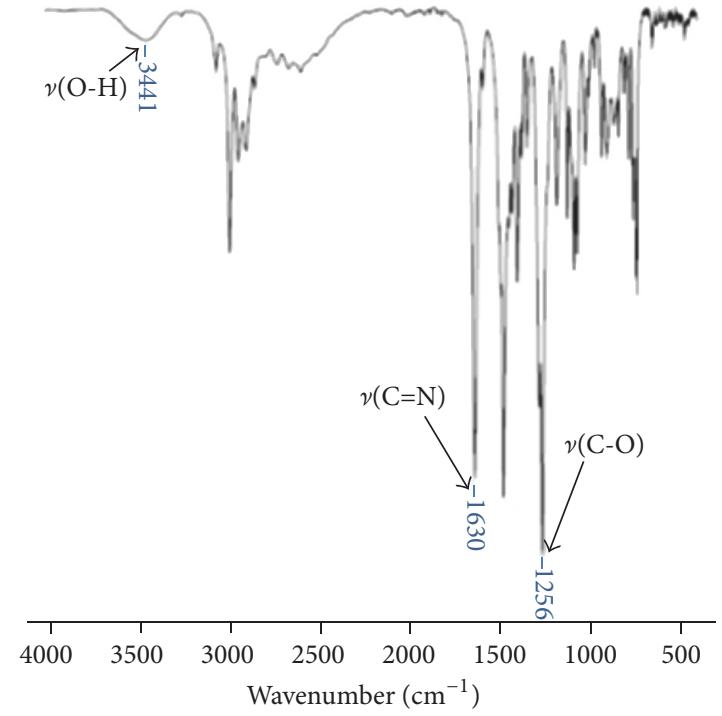

(a)

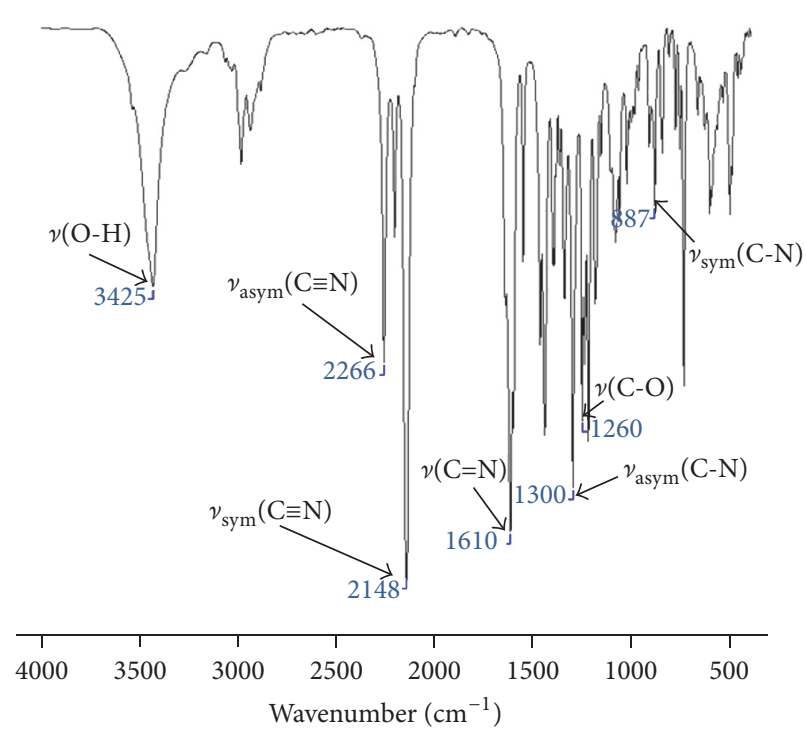

(b)

FIgURE 3: Comparison between the spectra for the free ligand $\mathrm{H}_{2} \mathrm{~L}^{2}$ (a) and complex 2 (b).

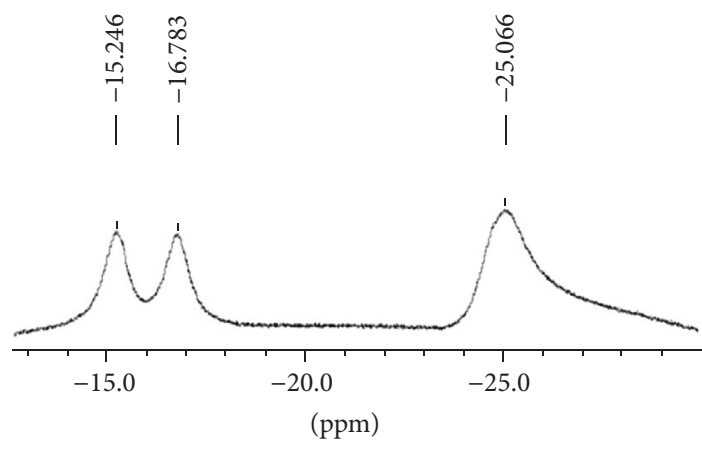

FIgURE 4: Paramagnetic ${ }^{1} \mathrm{H}$ NMR spectrum for complex 2.

TABLE 4: Selected bond lengths $(\AA)$ and angles $\left({ }^{\circ}\right)$ for complex $\mathbf{1}$.

\begin{tabular}{lc}
\hline $\mathrm{Mn}(1)-\mathrm{O}(830)$ & $1.870(15)$ \\
$\mathrm{Mn}(1)-\mathrm{N}(1)$ & $1.9816(19)$ \\
$\mathrm{Mn}(1)-\mathrm{N}(20)$ & $2.257(2)$ \\
$\mathrm{Mn} 1-\mathrm{O}(130)$ & $1.8705(15)$ \\
$\mathrm{Mn} 1-\mathrm{N}(8)$ & $1.9940(19)$ \\
$\mathrm{Mn} 1-\mathrm{O}(30)$ & $2.2859(18)$ \\
\hline $\mathrm{O}(830)-\mathrm{Mn}(1)-\mathrm{O}(130)$ & $91.03(7)$ \\
$\mathrm{N}(8)-\mathrm{Mn}(1)-\mathrm{O}(9)$ & $86.02(6)$ \\
$\mathrm{O}(830)-\mathrm{Mn}(1)-\mathrm{N}(1)$ & $176.10(7)$ \\
$\mathrm{N}(1)-\mathrm{Mn}(1)-\mathrm{O}(9)$ & $84.56(6)$ \\
$\mathrm{O}(130)-\mathrm{Mn}(1)-\mathrm{N}(1)$ & $92.72(7)$ \\
$\mathrm{O}(830)-\mathrm{Mn}(1)-\mathrm{O}(9)$ & $90.13(6)$ \\
\hline
\end{tabular}

in Figure 7 and main bond distances and angles are shown in Table 4.

The monomer is composed by an approximately octahedral $\left[\mathrm{MnL}^{1}\left(\mathrm{H}_{2} \mathrm{O}\right)(\mathrm{DCA})\right]$ unit. The planar tetradentate

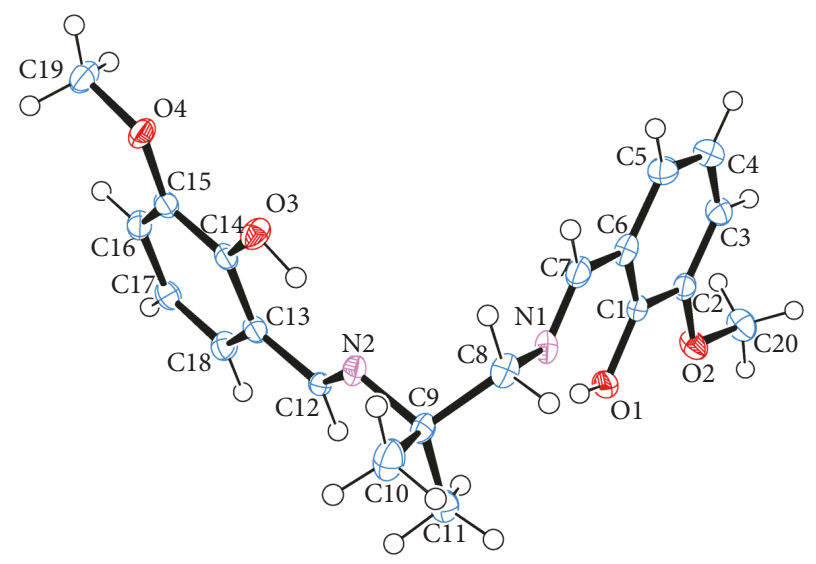

FIGURE 5: ORTEP representation (50\% probability) of $\mathrm{H}_{2} \mathrm{~L}^{2}$.

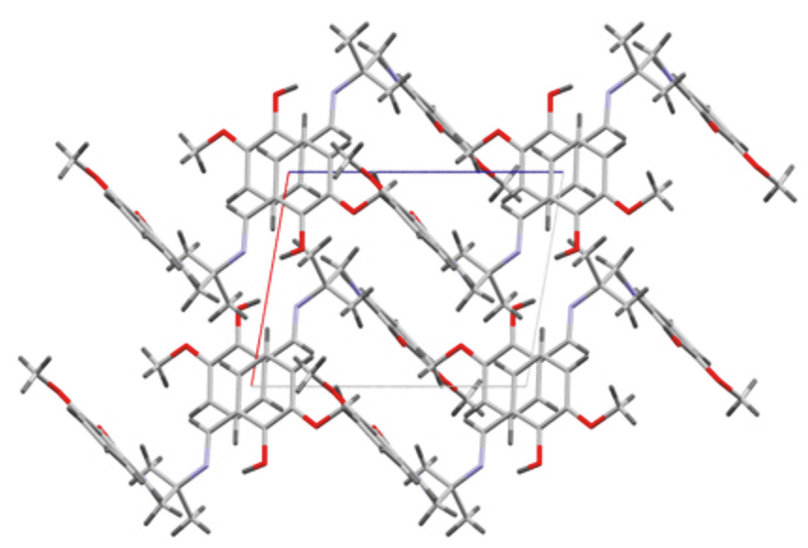

FIgURE 6: View along the $b$-axis for $\mathrm{H}_{2} \mathrm{~L}^{2}$. 


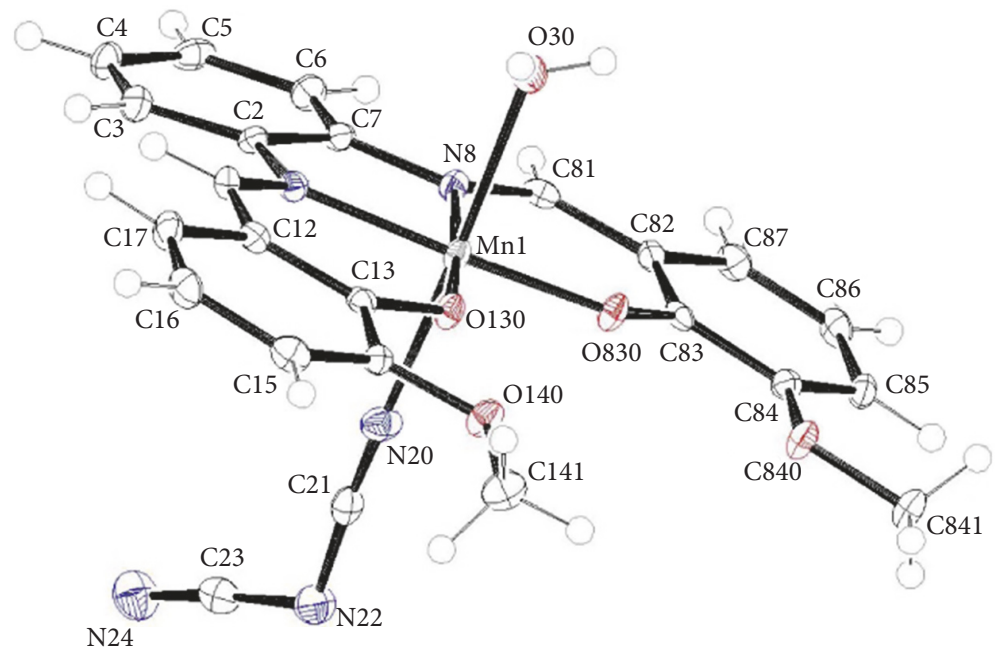

FIGURE 7: ORTEP view of the environment around the manganese ion in complex 1.

TABLE 5: Hydrogen bonds for complex 1.

\begin{tabular}{lcccc}
\hline $\mathrm{D}-\mathrm{H} \cdots \mathrm{A}(\AA)$ & $\mathrm{D}-\mathrm{H}(\AA)$ & $\mathrm{H} \cdots \mathrm{A}(\AA)$ & $\mathrm{D} \cdots \mathrm{A}(\AA)$ & $3.061(2)$ \\
\hline $\mathrm{O}(30)-\mathrm{H}(30 \mathrm{~A}) \cdots \mathrm{O}(130)^{*}$ & $0.83(2)$ & $2.43(2)$ & $2.908(2)$ & $134(2)$ \\
$\mathrm{O}(30)-\mathrm{H}(30 \mathrm{~A}) \cdots \mathrm{O}(141)^{*}$ & $0.83(2)$ & $2.12(2)$ & $3.034(3)$ & $158(2)$ \\
$\mathrm{O}(30)-\mathrm{H}(30 \mathrm{~B}) \cdots \mathrm{O}(830)^{*}$ & $0.76(3)$ & $2.40(2)$ & $2.922(3)$ & $141(2)$ \\
$\mathrm{O}(30)-\mathrm{H}(30 \mathrm{~B}) \cdots \mathrm{O}(840)^{*}$ & $0.76(3)$ & $2.23(3)$ & $3.449(4)$ & $152(2)$ \\
$\mathrm{C}(841)-\mathrm{H}(84 \mathrm{~A}) \cdots \mathrm{N}(24)^{* *}$ & 0.98 & 2.51 & & 160 \\
\hline
\end{tabular}

$*=-x,-y$, and $2-z ; * *=1-x, 1-y$, and $2-z$.

Schiff base $\mathrm{L}^{1}$ is tightly bound to the manganese ion through the inner $\mathrm{N}_{2} \mathrm{O}_{2}$ compartment by the $\mathrm{N}_{\text {imine }}$ and $\mathrm{O}_{\text {phenol }}$ atoms (Mn- $\mathrm{N}_{\text {imine }}$ bond lengths of 1.9816-1.9940 $\AA$ and Mn$\mathrm{O}_{\text {phenol }}$ of $1.87 \AA$ which are typical of such complexes [14-16]), occupying the equatorial positions. The geometry around the manganese ion can be described as distorted and octahedral with the axial positions of the octahedron occupied by a water molecule and a dicyanamide molecule. The axial distances of $2.2859 \AA$ (for $\mathrm{Mn}-\mathrm{O}(30)$ ) and $2.257 \AA$ (for $\mathrm{Mn}-\mathrm{N}(20)$ ) are considerably longer than the equatorial $\mathrm{Mn}-\mathrm{O}$ bond lengths quoted earlier, resulting in a rhombicity factor, expressed as the ratio between the $\mathrm{Mn}-\mathrm{O}$ axial and $\mathrm{Mn}-\mathrm{O}$ equatorial distances in the crystal structure, of 1.22. The deviation from an ideal octahedral geometry is also revealed by the range of angles observed around the metal centre (from $82.93^{\circ}$ to $\left.95.13^{\circ}\right)$, as well as by the interaxial angle $\mathrm{O}(30)-\mathrm{Mn}-\mathrm{N}(20)$ of $173.92^{\circ}$.

The octahedral $\left[\mathrm{MnL}^{1}\left(\mathrm{H}_{2} \mathrm{O}\right)(\mathrm{DCA})\right]$ entities are linked in pairs by $\mu$-aquo bridges between neighbouring axial water molecules and phenoxy and methoxy oxygen atoms and also by $\pi-\pi$ stacking interactions to give $\left[\mathrm{MnL}^{1}(\mathrm{DCA})\left(\mathrm{H}_{2} \mathrm{O}\right)\right]_{2}$ dimeric structures (Figure 8, Table 5). As a result of these supramolecular interactions, the $\mathrm{Mn} \cdots \mathrm{Mn}$ distances of about $4.96 \AA$ are short for monomeric compounds. These types of systems have been reported in literature $[15,16]$ as $\mu$-acuo dimers.

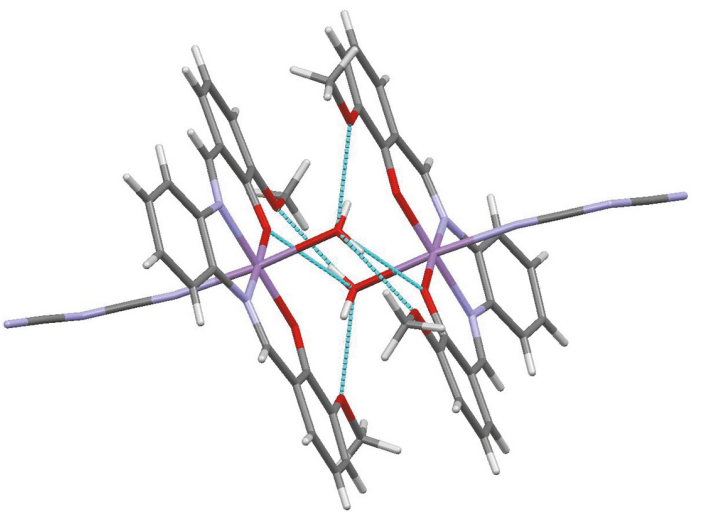

FIgURE 8: Stick diagram for the dimeric unit for complex 1 (manganese ion in magenta, oxygen in red, nitrogen in blue, and carbon in grey).

3.2. Peroxidase Studies. The peroxidase-like activity of $\mathbf{1}-\mathbf{3}$ was followed by the oxidation of the diammonium salt of $2,2^{\prime}$ azinobis-(3-ethylbenzothiazoline)-6-sulfonic acid (ABTS) at $\mathrm{pH}$ 6.8. During this reaction, ABTS is oxidized by hydrogen peroxide to the radical cation $\mathrm{ABTS}^{\circ+}$ [33] in the presence of the appropriate peroxidase mimic. While ABTS is colourless, its radical cation $\mathrm{ABTS}^{\circ+}$ is green, showing characteristic absorption bands that can be easily followed by 
TABLE 6: Peroxidase activity for complexes 1-22, axial and equatorial crystal distances around the manganese ion for each complex with solved crystallographic structure, resulting tetragonal elongation, and corresponding reference.

\begin{tabular}{|c|c|c|c|c|c|}
\hline \multirow{2}{*}{ Complex } & \multicolumn{2}{|c|}{ Crystal distances } & \multirow{2}{*}{ Tetragonal elongation $^{\mathrm{a}}$} & \multirow{2}{*}{ Peroxidase activity ${ }^{\mathrm{b}}$} & \multirow{2}{*}{ Reference } \\
\hline & $\mathrm{Mn}-\mathrm{O}_{\mathrm{ax}}$ & $\mathrm{Mn}-\mathrm{O}_{\mathrm{eq}}$ & & & \\
\hline $\mathbf{1}\left[\mathrm{MnL}^{1}(\mathrm{D})(\mathrm{DCA})\right]_{2}{ }^{\mathrm{c}}$ & 2.28 & 1.870 & 1.22 & $33 \pm 2$ & This work \\
\hline $2\left[\mathrm{MnL}^{2}(\mathrm{D})(\mathrm{DCA})\right](\mathrm{D})$ & un. & un. & un. & $53 \pm 3$ & This work \\
\hline $3\left[\mathrm{MnL}^{3}(\mathrm{D})(\mathrm{DCA})\right]$ & un. & un. & un. & $1.9 \pm 0.4$ & This work \\
\hline $4\left[\mathrm{MnL}^{4}(\mathrm{D})_{2}(\mathrm{DCA})_{2}\right]$ & 2.303 & 1.885 & 1.225 & $37 \pm 2$ & {$[16]$} \\
\hline $5\left[\mathrm{MnL}^{5}(\mathrm{D})_{2}\right]\left(\mathrm{NO}_{3}\right)(\mathrm{D})$ & 2.326 & 1.872 & 1.243 & $34 \pm 3$ & {$[22]$} \\
\hline $6\left[\mathrm{MnL}^{5}(\mathrm{D}) \mathrm{Cl}\right](\mathrm{D})_{2.5}$ & 2.318 & 1.878 & 1.234 & $31 \pm 2$ & {$[15]$} \\
\hline $7\left[\mathrm{MnL}^{5}(\mathrm{D})_{2}\right]\left(\mathrm{ClO}_{4}\right)$ & 2.314 & 1.865 & 1.24 & $19 \pm 2$ & {$[23]$} \\
\hline $8\left[\mathrm{MnL}^{6}(\mathrm{D})_{2}\right]\left(\mathrm{NO}_{3}\right)(\mathrm{D})$ & 2.373 & 1.862 & 1.27 & $50 \pm 3$ & {$[15]$} \\
\hline $9\left[\mathrm{MnL}^{7}(\mathrm{D})_{2}\right]\left(\mathrm{NO}_{3}\right)(\mathrm{D})$ & 2.263 & 1.880 & 1.203 & $32 \pm 1$ & [22] \\
\hline $10\left[\mathrm{MnL}^{8}(\mathrm{D})_{2}\right]\left(\mathrm{NO}_{3}\right)(\mathrm{D})$ & 2.271 & 1.870 & 1.214 & $33 \pm 1$ & {$[24]$} \\
\hline $11\left[\mathrm{MnL}^{1}(\mathrm{D})_{2}\right]\left(\mathrm{ClO}_{4}\right)$ & 2.36 & 1.851 & 1.27 & $30 \pm 3$ & [23] \\
\hline 12A $\left[\mathrm{MnL}^{2}(\mathrm{D})_{2}\right]\left(\mathrm{NO}_{3}\right)(\mathrm{D})$ & 2.246 & 1.871 & 1.200 & $29 \pm 1$ & {$[15]$} \\
\hline 12B $\left[\mathrm{MnL}^{2}(\mathrm{D})(\mathrm{D} 2)\right]\left(\mathrm{NO}_{3}\right)$ & 2.258 & 1.879 & 1.202 & $29 \pm 1$ & {$[15]$} \\
\hline $13\left[\mathrm{MnL}^{2}(\mathrm{D})(\mathrm{OAc})\right](\mathrm{D})$ & 2.282 & 1.893 & 1.205 & $33 \pm 1$ & {$[15]$} \\
\hline 14A $\left[\mathrm{MnL}^{2}(\mathrm{D})\left(\mathrm{O}_{2} \mathrm{CEt}\right)\right]$ & 2.308 & 1.869 & 1.235 & $28 \pm 2$ & {$[14]$} \\
\hline 14B $\left[\mathrm{MnL}^{2}(\mathrm{D})\left(\mathrm{O}_{2} \mathrm{CEt}\right)\right]$ & 2.338 & 1.876 & 1.246 & $28 \pm 2$ & {$[14]$} \\
\hline $15\left[\mathrm{MnL}^{2}(\mathrm{D})\left(\mathrm{O}_{2} \mathrm{CPe}^{n}\right)\right]$ & 2.339 & 1.865 & 1.254 & $39 \pm 2$ & {$[14]$} \\
\hline $16\left[\mathrm{MnL}^{9}(\mathrm{D})_{2}\right]\left(\mathrm{NO}_{3}\right)(\mathrm{D})_{2}$ & 2.25 & 1.872 & 1.202 & $18 \pm 1$ & {$[15]$} \\
\hline $17\left[\mathrm{MnL}^{10}(\mathrm{D})_{2}\right]\left(\mathrm{NO}_{3}\right)(\mathrm{D})_{2}$ & 2.243 & 1.889 & 1.187 & $2.0 \pm 0.4$ & {$[24]$} \\
\hline $18\left[\mathrm{MnL}^{11}(\mathrm{D})(\mathrm{D} 2)\right]\left(\mathrm{ClO}_{4}\right)$ & 2.203 & 1.863 & 1.183 & $3.2 \pm 0.4$ & {$[25]$} \\
\hline $19\left[\mathrm{MnL}^{12}(\mathrm{D})_{2}\right]\left(\mathrm{ClO}_{4}\right)(\mathrm{D})$ & 2.22 & 1.88 & 1.181 & $2.4 \pm 0.4$ & {$[26]$} \\
\hline $20\left[\mathrm{MnL}^{13}(\mathrm{D})_{2}\right]\left(\mathrm{ClO}_{4}\right)(\mathrm{D})$ & 2.21 & 1.90 & 1.163 & $2.1 \pm 0.4$ & [27] \\
\hline $21\left[\mathrm{MnL}^{14}(\mathrm{D})_{2}\right]\left(\mathrm{NO}_{3}\right)(\mathrm{D})_{2}$ & 2.206 & 1.904 & 1.159 & $1.1 \pm 0.3$ & {$[22]$} \\
\hline $22\left[\mathrm{MnL}^{15}(\mathrm{D})_{2}\right]\left(\mathrm{NO}_{3}\right)(\mathrm{D})_{2}$ & 2.258 & 1.888 & 1.196 & $1.8 \pm 0.3$ & [24] \\
\hline
\end{tabular}

${ }^{a}$ Tetragonal elongation expressed as the ratio between the manganese-axial oxygen distances and the manganese-equatorial oxygen distances. ${ }^{\mathrm{b}}$ Peroxidase activity expressed as percentage of conversion of ABTS to $\mathrm{ABTS}^{\circ+}$ measured 10 min after mixing the solutions; ${ }^{\mathrm{c}} \mathrm{D}=\mathrm{H}_{2} \mathrm{O}$ or other solvent molecule (such as $\mathrm{CH}_{3} \mathrm{OH}$ ); un.: unavailable (structure not solved).

UV-spectroscopy. The extent of the reaction can be measured quantitatively at $\lambda=650 \mathrm{~nm}$ since $\varepsilon=12000 \mathrm{M}^{-1} \mathrm{~cm}^{-1}$ has been determined [35].

In our experiments, an aqueous solution of ABTS $(50 \mu \mathrm{L}$; $\left.0.009 \mathrm{M} ; 4.5 \times 10^{-7} \mathrm{~mol}\right)$ and a methanolic solution of the corresponding complexes $1-3\left(10 \mu \mathrm{L} ; 10^{-3} \mathrm{M} ; 10^{-8} \mathrm{~mol}\right)$ were added to water. The intensity of the UV absorption bands of ABTS started to increase immediately after the addition of an aqueous solution of $\mathrm{H}_{2} \mathrm{O}_{2}\left(50 \mu \mathrm{L} ; 10 \mathrm{M} ; 5 \times 10^{-4} \mathrm{~mol}\right)$. The extent of the reaction can be measured quantitatively at $\lambda=650 \mathrm{~nm}$ since $\varepsilon=12000 \mathrm{M}^{-1} \mathrm{~cm}^{-1}$ has been determined. The peroxidase-like activity results are collected in Table 6 , where peroxidase activity is expressed as the percentage of the starting ABTS oxidized to its radical cation measured $10 \mathrm{~min}$ after mixing the solutions. The rate of formation of $\mathrm{ABTS}^{\bullet+}$ of about $33-53 \%$ indicates that $\mathbf{1}$ and $\mathbf{2}$ behave as efficient peroxidase mimics, while $\mathbf{3}$ does not present significant catalytic activity. Figure 9 shows the UV spectrum of the $\mathrm{ABTS}^{\circ+}$ radical cation obtained after $\mathrm{ABTS}$ reaction with $\mathrm{H}_{2} \mathrm{O}_{2}$ in presence of complex 2 , with the characteristic absorption bands at 415, 650,735, and $815 \mathrm{~nm}$.

Our previous findings in this field indicate a better catalytic behaviour when the substrate molecule is

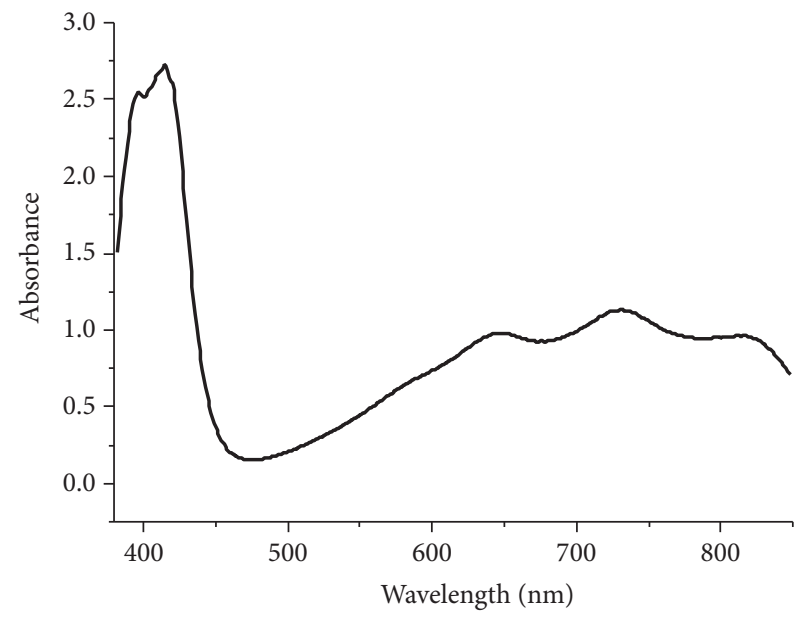

FIgURE 9: UV-Vis absorption spectrum of ABTS $+\mathrm{H}_{2} \mathrm{O}_{2}+2$, recorded $10 \mathrm{~min}$ after mixing the solution.

easily coordinated by the manganese complex, and this is favoured if the peroxidase mimic has either a vacancy in the coordination sphere or a labile ligand $[14,15]$. For the complexes used in this study, the high efficiency 


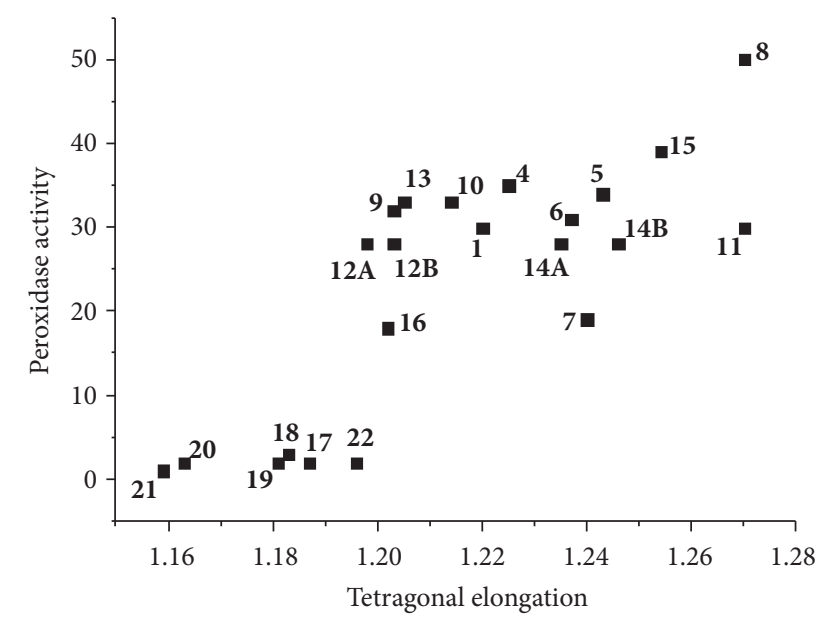

FIgURE 10: Peroxidase activity, expressed as percentage of ABTS conversion into $\mathrm{ABTS}^{\circ+}$, in function of the tetragonal elongation of the catalyst, expressed as the ratio between the $\mathrm{Mn}-\mathrm{O}$ axial and $\mathrm{Mn}$ O equatorial distances in crystal structures $\mathbf{1}$ and 4-22.

as peroxidase mimics found for complexes $\mathbf{1}$ and $\mathbf{2}$ can be explained in this sense. Complexes 1 and 2, derived from $\mathrm{H}_{2} \mathrm{~L}^{1}$ and $\mathrm{H}_{2} \mathrm{~L}^{2}$, respectively, have a short twocarbon chain between imine groups in the Schiff ligand. The short chain constricts the chelate ring once nitrogen atom coordinates with the metal and led to a tetragonally elongated octahedral geometry for the manganese complex. An axial water molecule in this class of distorted geometries constitutes a quite labile ligand, which would generate a vacant position in the coordination sphere to accommodate the substrate molecule. Besides, the two methyl groups located in the methylene spacer (bound to C9) in $\mathrm{H}_{2} \mathrm{~L}^{1}$, or the aromatic phenyl ring in $\mathrm{H}_{2} \mathrm{~L}^{2}$, increase the steric effect and probably increase the distortion of the octahedral symmetry. These structural factors, derived from these Schiff bases, provoke the high rates of peroxidase activity for the obtained manganese complexes $\mathbf{1}$ and $\mathbf{2}$. In the case of $\mathbf{3}$, the Schiff base ligand with a flexible three-membered alkyl chain between the imine groups favours a better stabilization of a highsymmetry octahedral geometry, which subsequently makes generation of a coordination site difficult. This type of flexible chain for 3 is similar for complexes 17-22 of Table 6.

In this way, a correlation between the factor of tetragonal elongation and peroxidase activity has been already reported [14, 15]. This tetragonal elongation may be calculated as the ratio between the manganese-axial oxygen distances and the manganese-equatorial oxygen distances of the complexes with known structures solved by X-ray crystallography (complex 1 and complexes 4-22). Table 6 gives the values for a number of complexes and Figure 10 shows the plot of the tetragonal elongation versus their peroxidase activity of this collection of complexes. The strength of this correlation is clearly checked in the present work using data from twenty-two solved crystallographic structures.

\section{Conclusions}

The synthesis and structural characterization of the Schiff base compounds $\mathrm{N}, \mathrm{N}^{\prime}$-bis(2-hydroxy-4-methoxybenzylidene)-1,2-diphenylendiimine $\left(\mathrm{H}_{2} \mathrm{~L}^{1}\right)$ and $\mathrm{N}, \mathrm{N}^{\prime}$-bis(2-hydroxy-4-methoxybenzylidene)-1,2-diamino-2-methylpropane $\left(\mathrm{H}_{2} \mathrm{~L}^{2}\right)$ have been reported. These two organic compounds behave as suitable ligands for coordination with metal ions, highly versatile due to different structural features: being tetradentate, ability to extend the hydrogen network using the outer methoxy groups, short and bulky spacer, etc. Three new manganese(III)-L-dicyanamide complexes have been obtained and characterized. The short twocarbon chain between imine groups in $\mathrm{H}_{2} \mathrm{~L}^{1}-\mathrm{H}_{2} \mathrm{~L}^{2}$ provokes tetragonally elongated octahedral geometries in the resulting complexes, which may increase their potential as catalysts for different applications. The correlation of peroxidase activity and the rhombicity caused by the short length of the Schiff base should be taken into account for designing new potential catalytic systems.

\section{Conflicts of Interest}

The authors declare that there are no conflicts of interest regarding the publication of this paper.

\section{Acknowledgments}

The authors are grateful for the financial support given by the Xunta de Galicia (GRC2014/025).

\section{References}

[1] W. Zhang, J. L. Loebach, S. R. Wilson, and E. N. Jacobsen, "Enantioselective epoxidation of unfunctionalized olefins catalyzed by salen manganese complexes," Journal of the American Chemical Society, vol. 112, no. 7, pp. 2801-2803, 1990.

[2] F. Song, C. Wang, J. M. Falkowski, L. Ma, and W. Lin, "Isoreticular chiral metal-organic frameworks for asymmetric alkene epoxidation: tuning catalytic activity by controlling framework catenation and varying open channel sizes," Journal of the American Chemical Society, vol. 132, no. 43, pp. 15390-15398, 2010.

[3] D. Tian, B. Liu, Q. Gan, H. Li, and D. J. Darensbourg, "Formation of cyclic carbonates from carbon dioxide and epoxides coupling reactions efficiently catalyzed by robust recyclable oncomponent aluminium-salen complexes," ACS Catalysis, vol. 2, no. 9, pp. 2029-2035, 2012.

[4] M. G. Dekamin, M. Azimoshan, and L. Ramezani, "Chitosan: a highly efficient renewable and recoverable bio-polymer catalyst for the expeditious synthesis of $\alpha$-amino nitriles and imines under mild conditions," Green Chemistry, vol. 15, no. 3, pp. 811820, 2013.

[5] A. M. Appel, J. E. Bercaw, A. B. Bocarsly et al., "Frontiers, opportunities, and challenges in biochemical and chemical catalysis of $\mathrm{CO}_{2}$ fixation," Chemical Reviews, vol. 113, no. 8, pp. 6621-6658, 2013. 
[6] W. Qin, S. Long, M. Panunzio, and B. Stefano, "Schiff bases: a short survey on an evergreen chemistry tool," Molecules, vol. 18, no. 10, pp. 12264-12289, 2013.

[7] M. M. Najafpour, G. Renger, M. Holynska et al., "Manganese compounds as water-oxidizing catalysts: from the natural water-oxidizing complex to nanosized manganese oxide structures," Chemical Reviews, vol. 116, no. 5, pp. 2886-2936, 2016.

[8] J. Safari, Z. Zarnegar, and F. Rahimi, "An efficient oxidation of benzoins to benzils by manganese(II) schiff base complexes using green oxidant," Journal of Chemistry, Article ID 765376, 2013.

[9] S. Doctrow, M. Liesa, S. Melov, O. Shirihai, and P. Tofilon, "Salen Mn complexes are superoxide dismutase and catalase mimetics that protect the mitocondria," Current Inorganic Chemistrye, vol. 2, no. 3, pp. 325-334, 2012.

[10] B. Day, "Catalase and glutathione peroxidase mimics," Biochemical Pharmacology, vol. 77, no. 3, pp. 285-296, 2009.

[11] P. A. Vigato, V. Peruzzo, and S. Tamburini, "Acyclic and cyclic compartmental ligands: Recent results and perspectives," Coordination Chemistry Reviews, vol. 256, no. 11-12, pp. 953-1114, 2012.

[12] S. Signorella and C. Hureau, "Bioinspired functional mimics of the manganese catalases," Coordination Chemistry Reviews, vol. 256, no. 11-12, pp. 1229-1245, 2012.

[13] M. W. Beck, S. B. Oh, R. A. Kerr et al., "A rationally designed small molecule for identifying an in vivo link between metalamyloid- $\beta$ complexes and the pathogenesis of Alzheimer's disease," Chemical Science, vol. 6, no. 3, pp. 1879-1886, 2015.

[14] M. R. Bermejo, M. I. Fernández, A. M. González-Noya et al., "Novel peroxidase mimics: $\mu$-Aqua manganese-Schiff base dimers," Journal of Inorganic Biochemistry, vol. 100, no. 9, pp. 1470-1478, 2006.

[15] M. Vázquez-Fernández, M. R. Bermejo, M. I. FernándezGarcía, G. González-Riopedre, M. J. Rodríguez-Doutón, and M. Maneiro, "Influence of the geometry around the manganese ions on the peroxidase and catalase activities of $\mathrm{Mn}$ (III)-schiff base complexes," Journal of Inorganic Biochemistry, vol. 105, no. 12, pp. 1538-1547, 2011.

[16] G. González-Riopedre, M. I. Fernández-García, E. GómezFórneas, and M. Maneiro, "Biomimetic catalysts for oxidation of lignin-like compounds," Catalysts, vol. 3, no. 1, pp. 232-246, 2013.

[17] G. González-Riopedre, M. R. Bermejo, M. I. Fernández-García et al., "Alkali-metal-ion-directed self-assembly of redox-active manganese(III) supramolecular boxes," Inorganic Chemistry, vol. 54, no. 6, pp. 2512-2521, 2015.

[18] C. J. Whiteoak, G. Salassa, and A. W. Kleij, "Recent advances with $\pi$-conjugated salen systems," Chemical Society Reviews, vol. 41, no. 2, pp. 622-631, 2012.

[19] Y. Yahsi, "X-ray characterization and magnetic properties of dioxygen-bridged CuII and MnIII Schiff base complexes," Acta Crystallographica Section C: Structural Chemistry, vol. 72, no. 7, pp. 585-592, 2016.

[20] Y. Pérez-Otero, M. I. Fernández-García, E. Gómez-Fórneas, G. González-Riopedre, and M. Maneiro, "Mimicking peroxidase activity by a manganese(II) Complex involving a new asymmetric tetradentate ligand containing both amino and imino groups," Journal of Chemistry, vol. 2015, Article ID 963152, 2015.

[21] M. Sundaramoorthy, M. Gold, and T. Poulos, "Ultrahigh $(0.93 \AA)$ resolution structure of manganese peroxidase from Phanerochaete Chrysosporium: implications for the catalytic mechanism," Journal of Inorganic Biochemistry, vol. 104, no. 6, pp. 683-690, 2010.

[22] M. A. Vázquez-Fernández, M. I . Fernandez-Garcia, A. M. González-Noya, M. Maneiro, M. R. Bermejo, and M. J. Rodríguez-Doutón, "Supramolecular networks of Mn(III)-Schiff base complexes assembled by nitrate counterions: X-ray crystal structures of 1D chains and 2D networks," Polyhedron, vol. 31, no. 1, pp. 379-385, 2012.

[23] M. R. Bermejo, M. I. Fernández, E. Gómez-Fórneas et al., “Selfassembly of dimeric Mn(III)-Schiff-base complexes tuned by perchlorate anions," European Journal of Inorganic Chemistry, no. 24, pp. 3789-3797, 2007.

[24] M. A. Vázquez-Fernández, M. I. Fernández-García, G. González-Riopedre, M. Maneiro, and M. J. Rodríguez-Doutón, "Self-assembled biomimetic catalysts: studies of the catalase and peroxidase activities of Mn(III)-Schiff base complexes," Journal of Coordination Chemistry, vol. 64, no. 22, pp. 3843-3858, 2011.

[25] M. Maneiro, M. R. Bermejo, A. Sousa et al., "Synthesis and structural characterisation of new manganese(II) and (III) complexes. Study of their photolytic and catalase activity and X-ray crystal structure of [Mn(3-OMe, 5-Brsalpn $\left.)(\mathrm{EtOH})\left(\mathrm{H}_{2} \mathrm{O}\right)\right] \mathrm{ClO}_{4}$," Polyhedron, vol. 19, no. 1, pp. 47-54, 2000.

[26] C. A. McAuliffe, R. G. Pritchard, A. Garcia-Deibe, A. Sousa, and M. R. Bermejo, "Diaqua-N,N' -trimethylenebis $\left(5^{\prime}\right.$-chlorosalicylideneaminato)manganese(III) perchlorate monohydrate: a Schiff-base complex linked into infinite spirals by hydrogen and bonds," Acta Crystallographica Section C, vol. 48, no. 2, pp. 364366, 1992.

[27] M. R. Bermejo, M. Fondo, A. Garcia-Deibe et al., "The diversity observed in manganese(III) complexes of tetradentate Schiff base ligands: an assessment of structural trends," Polyhedron, vol. 15, no. 23, pp. 4185-4194, 1996.

[28] U. Casellato, P. Guerriero, S. Tamburini, P. A. Vigato, and C. Benelli, "Mononuclear, homo- and heteropolynuclear complexes with acyclic compartmental Schiff bases," Inorganica Chimica Acta, vol. 207, no. 1, pp. 39-58, 1993.

[29] G. M. Sheldrick, SHELX-97 (shelxs 97 and shelxl 97), programs for crystal structure analyses, University of Göttingen, Germany, 1998.

[30] G. M. Sheldrick, SADABS, program for scaling and correction of area detector data, University of Göttingen, Germany, 1996.

[31] A. Majumder, G. Pilet, M. T. Garlan, and S. Mitra, "Synthesis and structural characterisation of three dicyanamide complexes with $\mathrm{Mn}$ (II), $\mathrm{Zn}$ (II) and Cd(II): supramolecular architectures stabilised by hydrogen bonding," Polyhedron, vol. 25, no. 13, pp. 2550-2558, 2006.

[32] M. H. Habibi, M. K. Sardashti, K. Barati, R. W. Harrington, and W. Clegg, "Crystal structures of new schiff bases N,N' -bis(2hydroxy-3-methoxybenzyl-idene)-1,4-diaminobutane and $\mathrm{N}$, $\mathrm{N}^{\prime}$-Bis(2-hydroxy-4-methoxybenzylidene)-1,2-diaminoethane," Zeitschrift fur Naturforschung - Section B Journal of Chemical Sciences, vol. 62, no. 4, pp. 621-624, 2007.

[33] M. Zampakou, V. Tangoulis, C. P. Raptopoulou, V. Psycharis, A. N. Papadopoulos, and G. Psomas, "Structurally diverse manganese(II)-diclofenac complexes showing enhanced antioxidant activity and affinity to serum albumins in comparison to sodium diclofenaco," European Journal of Inorganic Chemistry, vol. 2015, no. 13, pp. 2285-2294, 2015. 
[34] J. Mahia, M. A. Maestro, M. Vazquez, M. R. Bermejo, A. M. Gonzalez, and M. Maneiro, "N,N'-Bis(2-tosylaminobenzylidene)-1,2-ethanediamine," Acta Crystallographica Section C Crystal Structure Communications, vol. 56, no. 3, pp. 347-348, 2000.

[35] M. F. Zipplies, W. A. Lee, and T. C. Bruice, "Influence of hydrogen ion activity and general acid-base catalysis on the rate of decomposition of hydrogen peroxide by a novel nonaggregating water-soluble iron(III) tetraphenylporphyrin derivative," Journal of the American Chemical Society, vol. 108, no. 15, pp. 4433-4445, 1986. 

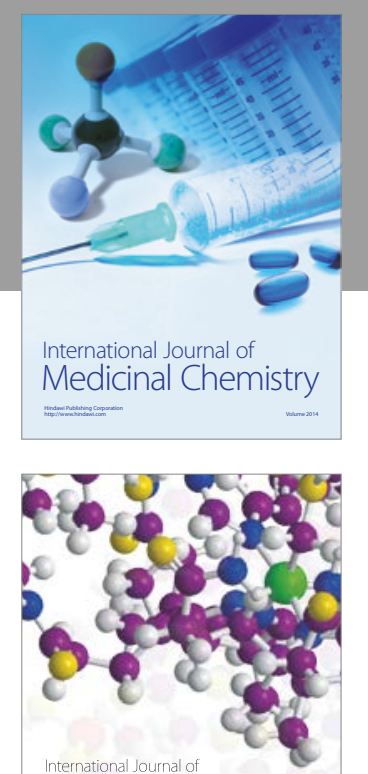

Carbohydrate Chemistry

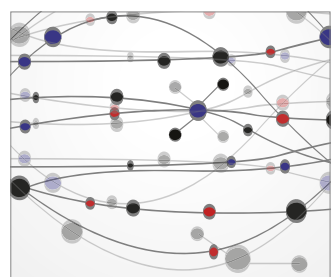

The Scientific World Journal
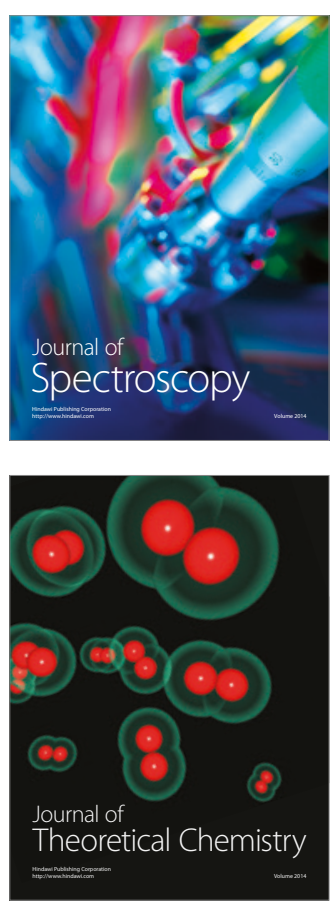
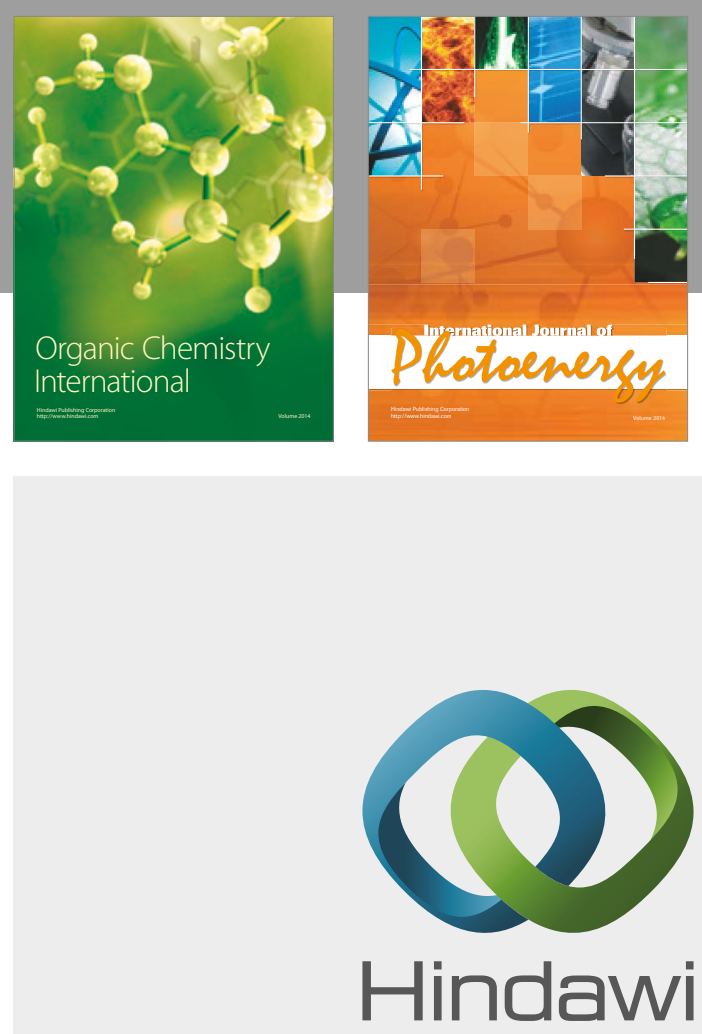

Submit your manuscripts at

https://www.hindawi.com

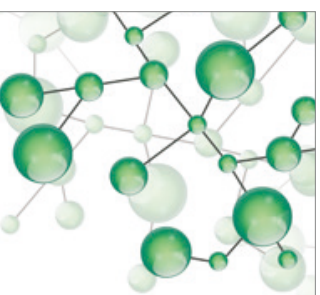

International Journal of

Inorganic Chemistry

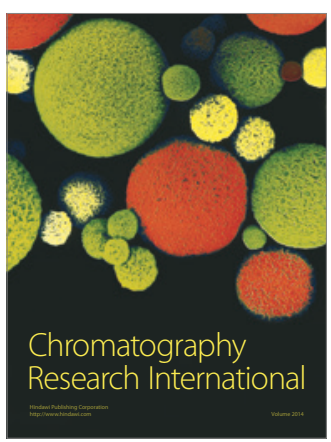

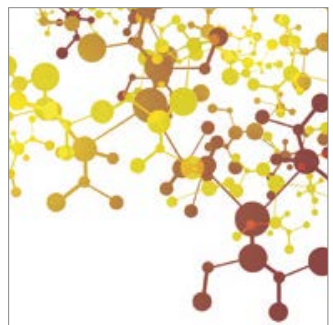

Applied Chemistry
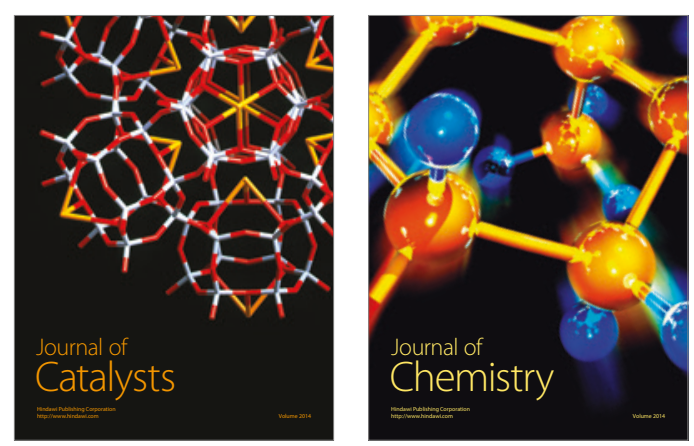
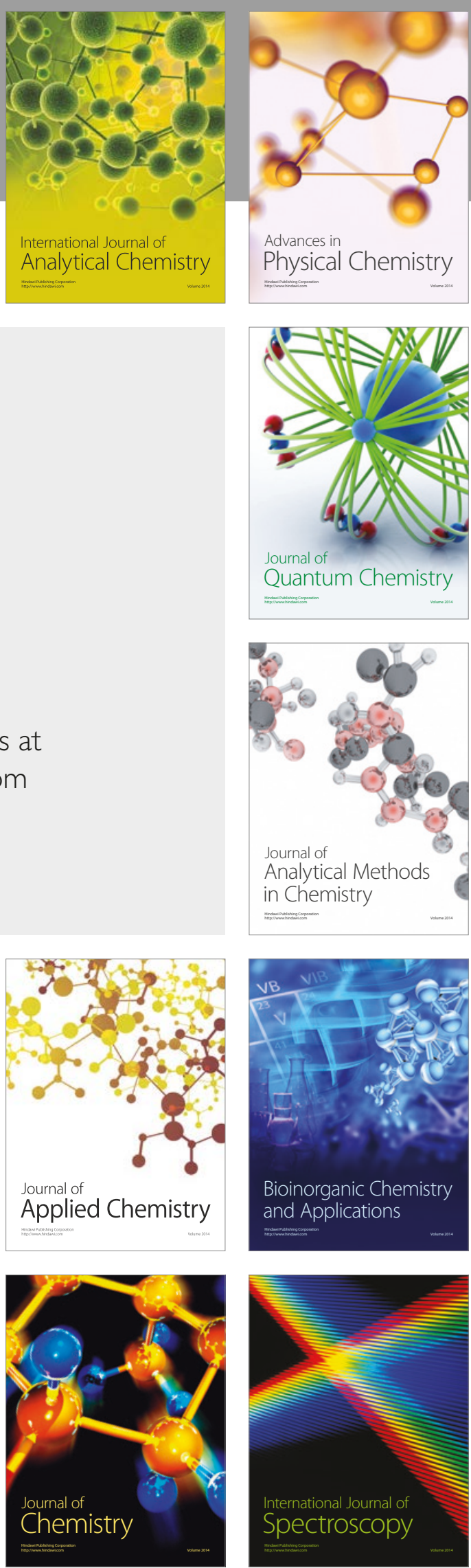